\title{
Practical-theological facilitation as skilled helping
}

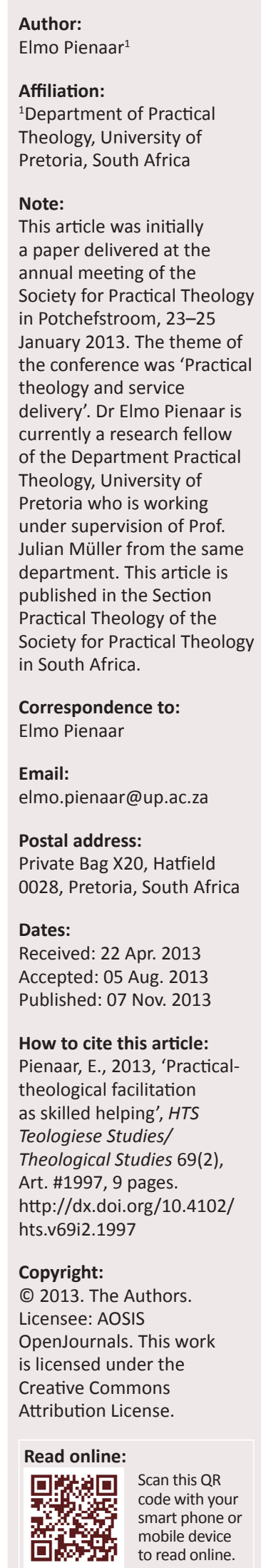

The article discussed the idea of skilled helping in relation to what has been put forward as practical theological facilitation. It has been argued that various helping relationships, amongst which the author refers to coaching, facilitation, and therapy has more in common than what differentiates them if epistemology is viewed as a unifying concept. As such the scope of practical theology in terms of the contexts and themes in which it might be involved is said to widen. The public dimension of the organisational context, more so than the congregational context, has been put forward as an important habitus of practical-theological facilitation. The organisational involvement of the practical-theological facilitator in terms of professional-vocational skilled helping takes on an actual role through facilitation and other helping modalities.

\section{Introduction}

The society of practical theology in South Africa held their 2013 conference on the theme of service and service delivery. ${ }^{1}$ The theme resonated with me from an organisational perspective. ${ }^{2}$ Whereas the theme of leadership tends to be one that raises a great deal of interest in the organisational context, the matter of service speaks particularly well ${ }^{3}$ to faith traditions that emphasise followership and servanthood. Although there is no specific research gap or, in conventional terms, a problem statement, the article contributes to the broader theme of the leadershipfollowership conversation. I place the ideas of being skilled, being a helper, and of practicaltheological facilitation within the context of followership.

The concepts that will receive attention are 'practical-theological facilitation' and 'skilled helping'. I am uncertain about how familiar the readership is with practical-theological facilitation as a discipline. It is a field that I am developing in theory and practice. Since I have already started to elaborate on practical-theological facilitation (cf. Pienaar 2012; cf. Pienaar \& Müller 2012), more attention will be given to the latter concept of the title, namely, skilled helping.

\section{Skilled helping}

\section{An understanding of skilled helping}

Many students have acquired entire libraries from former students during their theological studies. I dusted off two of the books I have received in this way for the purpose of this article. I have also had an unstructured interview with someone situated in the corporate environment to test several of the ideas in this article in respect of the habitus of practical-theological facilitation. Though it was before my time of studies the books I am referring to may in turn have been prescribed to some of the readership or indeed prescribed by some of the readership: Respectively they are titled The helping relationship, from Lawrence Brammer, and The skilled helper, from Gerard Egan. ${ }^{4}$ Although I have borrowed the phrase 'skilled helping' from Egan I have chosen to involve Brammer (1979) in this article. ${ }^{5}$

1.The conference was held at the Potchefstroom campus, North-West University from $23-25$ January, 2013. This article is based on a paper the author delivered at the conference relating to the theme of service and service delivery.

2.My research fellowship revolves around 'Narrative and spiritual coaching in organisational development.'

3. With this remark I do not discount literature that brings to the body of knowledge on leadership the theme of servanthood. Of particular interest is the work of Robert Greenleaf (cf. Greenleaf n.d.). See also the anniversary edition of Servant leadership (cf. Greenleaf 2002), notable for its foreword by Stephen Covey and its afterword by Peter Senge.

4.The first edition seems to have been printed in 1975 (cf. http://www.goodreads.com/work/editions/1514963-the-skilled-helper-aproblem-management-and-opportunity-development-app). Its popularity is to a degree confirmed by the fact that a tenth edition was problem-management-and-opportunity-development-app). Its popularity is to a degree confirmed by the fact that a tenth edition was
released, spanning almost four decades: Egan, G., 2013, A problem-management and opportunity-development approach to helping, 10 th edn., Brooks Cole, Pacific Grove, CA

5.The purpose of involving Brammer is not aimed at comparing our ideas. I merely wish to present the basic assumption he makes in service to the conference theme where this article was presented as a paper (see fn. 1). This early work of his (cf. Brammer 1979), being the second edition, is relevant in that it reflects a body of knowledge that was at one stage prescribed to, or by, some of the members of the practical-theological audience I addressed. The crux of our respective ideas, and the fact that I am using an earlier edition, suggest that an attempt to compare our views at length will not be relevant here. 
Depending on one's own persuasions both the words 'skilled' and 'helping' can be seen as problematic. It is by no means the only factor, but I agree with Brammer (1979:2) that our understanding of helpfulness is informed by our cultural frameworks. This encompasses the special meanings and unique language associated with help in a particular culture and is concretely influenced by race, ethnicity, and gender (Brammer 1979:2). Tracy (1994:134) refers to these as one's 'social location' ${ }^{6}$ relevant to a new conceptualisation of hermeneutics ${ }^{7}$ instead of 'historical context'. What I would like to add to Brammer (1979) in respect of that which influences one's views on being skilled and on helping - in addition to our cultural framework - is one's ethical-political inclination and epistemological persuasion.

Let me state early on what my intention is with the phrase. To me, skilled helping is associated with serving. It has more to do with followership than leadership, with listening than speaking, with saying you do not know when you do not and being humble about what you do know, and with accompaniment as opposed to being a quick fix. I therefore agree with Brammer (1979:7) that helping people with a 'presumed goal of doing something for them, or changing them in some way, has an arrogant quality'. It should therefore be clear that I do not work with a deficit model, with the assumption that something is wrong - not in any of the modalities of practical-theological facilitation, such as coaching, facilitation, or therapy. Along with Freedman and Combs (1996:15), I am not interested in solving problems, as such, but in developing alternative stories. Freedman and Combs (1996:15) found that rather focusing on alternative stories went beyond problem solving.

\section{The premise of skilled helping}

The main value of the phrase 'skilled helping' lies in the premise Brammer holds, and not so much with the bulk of what Brammer puts on the table. What is Brammer's premise? Brammer (1979:3) affirms that he works with the assumption that the basic interpersonal communication processes implied by the following forms of helping are similar: counsellorcounselee, worker-client, therapist-patient, parent-child, teacher-pupil, and interviewer-interviewee. As a consequence of these being similar he opts for the basic descriptions of helper and helpee (Brammer 1979:3-4).

Some of the helping relationships that I have in mind are counselling and therapy, facilitation, coaching, and consulting (but with the adage of qualifying it as facilitative consulting). There are other roles or relationships that also pertain. The ones I mentioned, however, most clearly relate to helping. I also propose with Brammer (1979:3-4) that these have something significant in common, that they are perhaps more alike than different. If the argument holds, then practical theologians or clergy might want to consider that there is more to their helping capabilities than having it restricted to pastoral care and counselling within the congregational or academic setting unless that is, of course, their singular interest.

6.Tracy (1994:134) specifically has gender, race, and class in mind.

7.See footnote 19 that relates to 'new hermeneutics'.
Whilst Brammer (1979) places the emphasis on interpersonal communication, I in turn argue that the premise holds true in instances where one places weight on epistemology as a unifying idea. Epistemology is therefore more than a vague or abstract concept; rather an intentional operational idea that finds significant expression in practical theology because of its practice, and indeed praxis orientation. A focus on epistemology is at once a deconstruction of the boundaries between these modalities, such as between therapy and coaching. All of these modalities can, therefore, merely be referred to as helping.

Emphasis on epistemology further implies that the contexts and themes that one could become involved in through these modalities are indeed very wide. The scope of practical theology (in terms of its field of inquiry and practice) therefore widens considerably, but there is a stronger emphasis on the epistemology that informs inquiry and practice. Although rather for epistemological reasons, I have the same view as Brammer (1979:5) that '... there are many labels for substantially the same helping process.' If our labels for helping are kept intact - I suspect they will, as the dominant discourses on management, psychology, professionalism, and other matters are very persistent - then the 'overlapping functions of helping specialities is [and will remain] a confusing reality' (Brammer 1979:5).

\section{A brief introduction to practical- theological facilitation}

In a previous article (cf. Pienaar 2012), I have indicated that I think practical-theological facilitation can be practiced in a professional-vocational capacity. I specified that the word facilitation is sometimes used colloquially, but furthermore, that relevant literature connotes the idea of facilitation as a skilful-postural stance, on the one hand, and a professionalvocational role on the other (Pienaar 2012).

I deem it necessary to underscore vocation as a motif for the practical theologian acting in a professional-vocational role. The reason for this is that it then becomes a service. Generally, a distinction is made between a product and a service (cf. Nationalarchives n.d.). ${ }^{8}$ Some services carry the connotation of being 'professional' (cf. Kroes 2005). Apart from perhaps being a statement of quality, services that are deemed 'professional' are often associated with money as a form of exchange for the rendering of the service in order to address the needs of a client. As such, the motif of making money is directly linked to 'the professional' and the services that are offered, as opposed to 'the product'. The reference to 'vocation' emphasises a significant aspect; of not making money but making meaning. ${ }^{9}$ It is foremost the collective and collaborative meaning-making aspect of practical-theological facilitation - a form of skilled helping - that I have in view.

For my point of departure, I work with David Tracy's (1981/1998) three 'publics' of theology: society, academy, and

8.See also Wikipedia (n.d.).

9.A vocational understanding is not reserved to ministry related professions. 
church. I, however, refer to these as the audiences of practical theology and differentiate between the public, academic, and ministry audiences. ${ }^{10}$ In the field of practical theology these audiences are important to practical-theological facilitation. However, with the hopefully foregone idea of restricting practical theology to the activities of the minister (cf. De Roest 1998:26) and consequently to skills application (téchne) of scientific theological insight (theoría) (cf. Browning 1991:34), it was perhaps the ministry environment that received the greatest deal of attention.

My critique here is that it involves a restrictive focus; it is congregational and believer-centric. Arguing whether this is still the way that practical theology is conceived of ${ }^{11}$, matters less than perhaps the fact that this is still how it is often organised, as pastoral care, congregational studies, liturgy, homiletics, and catechesis. If this is the structure that we still seem to choose - a matter that coincidently relates to organisational theory and design - then it could be said we are still seeing practical theology as belonging to De Roest's (1998:26) traditional practical theology, namely, the clerical paradigm. ${ }^{12}$

It is important to realise that our subdivisions can be said to have an outer public dimension. Naturally these are not mirror images. Pastoral care could perhaps relate to Human Resources functions and the work of organisational psychologists. Congregational studies speak to organisational studies (including organisation theory, development, design, behaviour, and discourse). Homiletics could in general relate to the art of rhetoric in any profession. Liturgy in some respects deal with what happens when organisations convene on certain matters and in various expressions that might show towards cultural-organisational rites of passage, induction practices, and performance of norms as rituals in organisations and institutions. Catechesis relates to teaching and learning that spans pedagogy to andragogy.

There is more to keep in mind when considering the significance of what I refer to as the 'outer dimension' of practical theology: Themes that one might consider relevant to theology (e.g. religion and spirituality), are also attended to by non-theologians in the outer dimension. These are topics that theology does reflect on from the perspective of various peer theological disciplines. This is indeed part of what practicaltheological facilitation does, but importantly doing so with interest in the entire context (i.e. the broad outer dimension).

Add another layer of importance. Interest in the outer dimension is not only from the perspective of practice orientation, but practice participation. All theology, to various

10.My initial engagement with Tracy's three 'publics' was when I attended a lecture of Professor Ruard Ganzevoort at the University of Pretoria. Ganzevoort does not distinguish between using the terms 'public' and 'audience' although he refers to the publics in relation to practical theology (Ganzevoort 2009, 2013). Tracy (1981:3) sees all theology as public theology (and I agree), but whereas I speak of a public, academic, and ministry audience (cf. Pienaar \& Müller 2012), Tracy refers to 'society', 'academy', and 'church'.

11.What comes to mind is one of Browning's (1991) significant contributions proposing that all theology is fundamental practical theology and that of Volf and Bass (2002) implying that theology cannot be dissociated from practice, since all theology is about practicing theology.

12.De Roest (1998:26-27) distinguishes a four-part development in the history of practical theology. degrees, relates to practice orientation (cf. Volf \& Bass 2002). Practical-theological facilitation underscores practice participation. Pienaar and Müller (2012:3), following De Roest (1998), note that the concept of handlungswissenschaft [a science of action] was relevant to the growing understanding of practical theology as a discipline. The description of a science of action can be said to relate strongly to social sciences. To me the humanities play at least as an important role in practicaltheological facilitation as the social sciences. I do, however, have an affinity for the description handlungswissenschaft, as my association with it is more one of practice participation than practice orientation. When the term handlungswissenschaft is permeated with a humanities understanding, the phrase is not restricted to a 'science of action', but enhanced with the view of a 'science in action.' The humanities qualify practicaltheological facilitation, being a handlungswissenschaft, most pertinently as praxis.

To concretise it more I mention two examples of where the theme of spirituality forms part of the inquiry of other disciplines: Firstly, there is a context in coaching referred to as transpersonal coaching. In this type of coaching the 'transpersonal is a level of consciousness where we admit that we are spiritual beings with a soul and a spirit' (Rowan 2010:146). Transpersonal is regarded as a scientific concept, better to work with than spirituality, which is perceived to be too vague (Rowan 2010:147). Robert Assagioli, known for the concept and practice of psychosynthesis (a term that his friend and colleague Carl Jung proposed), became a primary influence in what would later be called transpersonal psychology (Whitmore 2003:121). Whybrow and Wildflower (2011) discuss humanistic and transpersonal psychology. They note that 'transpersonal psychology explores states of consciousness that have been traditionally associated with mystical and spiritual experiences' (Whybrow \& Wildflower 2011:9). Griffith and Griffith (2002) discuss the notion of discovering the sacred in psychotherapy. Sellers (2011) write about spiritual and religious traditions in coaching.

Then, secondly, there is a growing body of knowledge that relates to the theme of spirituality in the workplace. Badrinarayanan and Madhavaram (2008) remark:

Recent years have witnessed a proliferation of articles on spirituality and its relevance for business. A growing trend in spirituality research is an emphasis on spirituality in the workplace. Theoretical and empirical support is slowly emerging on how workplace spirituality influences both employee and organizational outcomes. (p. 421)

In addition to the interest that the practical-theological facilitator takes in the outer dimension of a traditional conceptualisation of practical theology it can be expected that the theme of 'spirituality in the workplace' would form part of various conversations relating to the outer dimension. That there is a handbook of workplace spirituality and organisational performance attests to it that this topic has reached a degree of responsible formalisation (cf. Giacalone \& Jurkiewicz 2010).

Practical-theological facilitation goes further and considers practice participation in addition to practice orientation or scientific reflection. As such, it is necessary to develop the 
theoretical foundation for participation and inquiry from the perspective of the discipline of practical theology.

\section{The habitus of practical-theological facilitation}

The brief introduction to practical-theological facilitation established that it is, amongst other things, concerned with the theme of spirituality, and in that, with particular focus on the public or outside audience. In what follows, the habitus is also seen to be wider than personal spirituality. Thereafter some arguments are put forward in respect of the knowledge requirements of the habitus.

\section{Spirituality as organisational characteristic}

Badrinarayanan and Madhavaram (2008) accentuate that, in their paper, workplace spirituality is not foremost conceptualised as an individual - I refer to it as a 'personal' - trait or state, but as an organisational characteristic (Badrinarayanan \& Madhavaram 2008:424). To emphasise then: The interest of practical-theological facilitation is firstly on the outer dimension as opposed to the clerical paradigm. The interest relates to spirituality, but both in respect of the experience of the individual (i.e. the personal context), and that of the organisation (i.e. the corporate context).

This is part of what I consider 'public' to mean: Outside of the confines of inwardly focused private Christian religious and congregational inquiry and practice. This 'outside' should not be confused with missiology, as practical-theological facilitation is not about how 'the good news' (i.e. euangelion) is lived, expressed, or expanding. If it is not missiology, then it is certainly also not about Christian initiatives to reach the marketplace. These are some of the places I have found people see in their minds when I talk about practical-theological facilitation in the organisational context or habitus.

When speaking of this outer dimension of the public audience, my argument is that organisations in general (though less so, but not excluding the church), become important. The economy is one of the driving metaphors in society, and all kinds of organisations and institutions play their part. Consequently, the nations of the world and all kinds of economic stakeholders see it fit to attend forums such as the annually held 'World Economic Forum. ${ }^{13}$ This forum takes as its objective to encourage:

businesses, governments and civil society to commit together to improving the state of the world. Our Strategic and Industry Partners are instrumental in helping stakeholders meet key challenges such as building sustained economic growth, mitigating global risks, promoting health for all, improving social welfare and fostering environmental sustainability. (World Economic Forum n.d.)

This suggests that organisational theory (design, behaviour, development, and discourse) should to some extent be part of the critical body of knowledge in practical-theological facilitation. ${ }^{14}$

13.For a useful overview of the issues on the forum's agenda see http://www.weforum org/issues

14.I should mention that the habitus cannot be restricted to a particular context. Most preferably it is the story of the practical-theologian facilitator that should lead to a particular context, or being involved with particular themes.
Practical-theological facilitation has implications for the understanding of public theology that I cannot develop fully in this article. Practical-theological facilitation formally adds a dimension to public theology that has not received the emphasis that I would argue will see it make a still greater contribution. Whereas public theology and publicfocused practical theology would hold that there should be participation in public discourse, practical theologicalfacilitation adds how this might take place with greater effect.

\section{Knowledge requirements in respect of the habitus}

Return for a moment to the theme of knowledge and particularly content knowledge as critical knowledge: Content knowledge refers to subject knowledge, very concretely, often specialist knowledge. To say that the practical-theological facilitator should have content knowledge, I suspect, will not pose a problem in traditional discourses in terms of what constitutes science (or practice); in other words, those things the larger scientific community says a particular discipline is about.

It is, however, another matter in the epistemology I am positioned relating to postfoundationalism, social constructionism, and narrative practice ${ }^{15}$, where content knowledge and its effects, particularly in the context of the helping relationship, can be contentious. The concern relates to what ethical posture the 'expert' sees as informing his or her helping role (cf. Freedman \& Combs 1996:269). My view is that practical-theological facilitators have to have some form of content knowledge. It may even be that they know more than those in the organisation they work with regarding, for example, culture, teams, strategy, organisational types, organisational discourse, and so on.

For the skilled helper of the practical-theological facilitator, knowledge for the sake of being a specialist is not the end destination. What is stressed is the importance of learning a language and engaging a culture effectively. This is a cumbersome task, as culture encompasses many things. Daft (2010) describes organisational culture as:

the set of values, norms, guiding beliefs, and understandings that is shared by members of an organization and taught to new members as the correct way to think, feel, and behave. It represents the unwritten, feeling part of the organization. (p. 374)

Gaining content knowledge through language acquisition is also true to the spirit of facilitation, bearing in mind that facilitation strongly associates itself with process knowledge rather than content knowledge (Bens 2005:5-6). In my correspondence with professional facilitator and member of the International Association of Facilitators, Monique Carnino (01 March 2012), she attests to this. She indicates that prior to engaging a client in a facilitation process she tries to learn something of, for instance, the topic, industry, or technology. If the facilitation involves executive members of a bank she will go into the facilitation process with general knowledge

15.Please see Müller's (2011) article on postfoundational practical theology, as my aim is not to explain the epistemology of postfoundationalism and social constructionism. Müller's (2011) article connects both the idea of stories and social constructionism to postfoundationalism. 
of the banking industry, but then also the particular bank and the specific team. Learning also includes getting somewhat familiar with, for instance, the acronyms used by leaders and staff. She does this either during the contracting phase in a one-on-one meeting with the primary client, or a person that is close to the group. This information helps her in three ways, namely, (1) to follow the conversations better, (2) to plan for the facilitation itself, and (3) to help her make sense of the output of the facilitation sessions that serve as the basis for ongoing work with a client.

In addition to a proposed critical body of knowledge about organisations, the story of the practical-theological facilitator has an important role to play in further knowledge development and acquisition. Deriving from or building towards a personal narrative any number of themes or defined contexts could be held in view for learning, for example, strategy development, change management, aspects of leadership, and more. This adds to the credibility of the practical theologian who is participating from a relational constructionist posture instead of from a propositionalist, or, truth-claim perspective.

The theme of the importance of language acquisition has remained with me for some time and is relevant to the personal narrative of the practical-theological facilitator. In my doctorate thesis I had a section on 'Research as acquiring a new language' (Pienaar 2005:32-38). Therein I quoted a conversation with Professor Karlijn Demasure ${ }^{16}$ where she states that language is not only seen as part of a culture, but as a product of culture. One can also argue that language functions as a generator of culture. The point is that the relationship between language and culture is everything but static. These views hold that it is important for the practicaltheological facilitator to be able to understand and speak the relevant language pertaining to the context, theme, or culture.

I tested the idea of a practical-theological facilitator functioning as skilled helper with someone who is experienced in the organisational context.

\section{The practical-theological facilitator in the organisational context}

I now briefly introduce the person with whom I conducted the interview.

\section{Pleased to introduce ...}

I set up an explorative interview with Riaan Cloete about the potential value that a practical theological-facilitator might add in the organisational context. Subsequent remarks relate to our interview on 18 January $2013 .{ }^{17}$

16.Demasure, K., 2005, 'Lectures on the hermeneutics of Paul Ricoeur and an introduction to social constructionism', presented at the University of Pretoria, Pretoria, 27 September. Her academic profile can be seen here: http://ustpaul.ca/ Pretoria, 27 September. Her academ
index.php?mod=employee $\&$ id $=389$

17.This article has not been published without consent from the interviewees in respect of feedback on content-interpretation, the light in which the interviewee is placed, and matters pertaining to anonymity and specificity of information.
Riaan is a former director at a life insurance services firm where he had overseen accounting and financial matters. He is a current director at a holistic financial services firm and co-develops an entrepreneurial venture.

There is also a shared childhood history with Riaan, about our escapades as a 'bende' [a gang], with him being the leader and me the number two guy. My view on these early experiences of being 'number two' fits into the story of the relevance of facilitation. The rank metaphor is somewhat restrictive in terms of what it conveys. Allow me to reframe it: In the spirit of this article, being number two speaks of taking up a particular role, albeit in a professional-vocational capacity. The person who ends up crossing the line first can only do so if there are others taking part who fulfil this followership role.

\section{The relationship between the practical-theological facilitator and the organisation - off to a wise start?}

Along the lines of such a relationship between number one and two, I attempted to explain to Riaan the relationship of the practical-theological facilitator to the organisation by comparing it to that of a prophet to Israel, Nathan to David, perhaps Merlin to King Arthur. These metaphors are in certain respects misleading, but Riaan associated it with the role of a corporate advisor. This theme served as our platform for further exploration.

He asserted that what I am explaining could be useful, but not necessarily only on executive level, as that is not where the hardest part of change lies. He says that it is remarkable that in some instances executive level decision-makers can agree and act fairly quickly. The difficulty, in his opinion, lies with fostering change and creating culture. In terms of change the modalities of coaching, counselling, facilitation and so on, can be very useful.

I felt inclined to say more about what he associated with helping in view of his connotation with an advisory role. I qualified that the practical-theological facilitator does not assume to know more about the organisation or industry or any particular body of knowledge than the client. Neither the value proposition of the practical-theological facilitator nor the skill of skilled helping relates to superior content knowledge as such. Embroidering on the possibilities of what the Merlin analogy might hold, I tried to then explain that the advisory role had more to do with wisdom, with skilled accompaniment and collaboration. I did initially tell Riaan that the role should preferably be fulfilled by an older person. He then noted that it is not necessarily the case that organisations seek the services of the older (undoubtedly having the connotation of being wiser) person. Then again he also referred to me and him as old, and I laughed.

Gerkin's (1986) image of the pastor as an 'interpretive guide' comes to mind. It is relevant that he places this image in the operation of common sense (Gerkin 1991:68) by linking it to Gadamer's aesthetic understanding of the function of wise judgement (Gerkin 1991:69). Gerkin's (1991:69) metaphor 
capitalises on the idea of pastoral wisdom both in terms of the 'Christian narrative tradition, and the contemporary situations encountered in everyday life.' The notion of the wise (as the connotation with Merlin for instance), can easily mislead to frame the practical-theological facilitator as a person with superior mystical industry knowledge.

Riaan's remarks had me thinking afterwards about what it is that I wanted to convey with the notion of the wise, considering that I spontaneously followed the analogy. Wisdom has more to do with wisdom-making as a collaborative enterprise than wisdom-provision. In relation to the organisational context, wisdom-making lies close to the work of Karl Weick on 'sense-making'. ${ }^{18}$ In my native discipline, namely, narrative pastoral care and counselling, it brings to mind narrative ideas of Michael White and David Epston concerning the performance of meaning (White \& Epston 1990, cf. Freedman \& Combs 1996:88), or one might say 'meaning-making'. Other concepts also relate to this idea: that of 'practical reason', 'practical philosophy', 'practical wisdom' (Browning 1991), the well-known conversation in practical theology regarding 'téchne', 'theoría' and 'phronēsis' (Browning 1991:10,34), and add to that the concept of 'praxis' as actionful thought and thoughtful action. It is also within this tradition of understanding practical theology as practical wisdom (Browning 1991:34, Müller 1996:1) that I place the operation of practical-theological facilitation.

\section{A humanities endeavour}

The wisdom I am referring to underscores collaborative interpretation or the making of meaning (hence, meaningmaking) as opposed to wisdom that attempts to find meaning. The only way one can use these concepts together is to say that meaning is indeed to be found, but in its making.

This view of wisdom stands alongside mentioned ideas - for instance 'practical reason' - and reveals a particular affinity with the human sciences more so than the social sciences. It does not exclude the social sciences, but implies that the pursuit of practical-theological facilitation is hermeneutical. ${ }^{19}$

With David Tracy's revision of his correlational model, the link that I see between practical theological-facilitation and the humanities becomes clearer. He revises his model to incorporate art and aesthetics (Tracy 2011:49-61). With this inclusion, the consequence is one of a return to spiritual exercises in practical theology (Tracy 2011:55). That he sees these as belonging together is clear:

In my 1983 article on practical theology I wrote of the need to correlate practical theology with ethics. Here I wish to add the aesthetic. An aesthetic-ethical correlation should, in turn, aid the further development of mystical-prophetic practical theologies. (Tracy 2011:50)

18.Prominently so titled with the two books Sensemaking in organizations (1995) and Making sense of the organization (2009).

19.I am referring here to Tracy's (1994:134) mention of a 'new hermeneutics': The emphasis is on social location more so than historical context, and discourse more so than text. The idea of working from the perspective of story-bearing in mind it is undergirded by social constructionism and postfoundationalism - supersedes both conceptualisations of hermeneutics. Or at the very least what one should say is that the matter of hermeneutics is placed within a different epistemology.
A practical theology that is attuned to the humanities will see as part of its makeup (its inquiry and practice) the arts and aesthetics, and wisdom and spirituality. Understandably then, in practical-theological facilitation, collaborative wisdommaking and the organisational theme of spirituality go together. Practical-theological facilitation as skilled helping, with its affinity to the humanities, is naturally aligned with what is understood as the renewed relevance of sacralisation of work (cf. Badrinarayanan \& Madhavaram 2008:426). ${ }^{20}$

This strengthens the idea of lending a stronger voice to humanities in the workplace than perhaps it had before. Inquiry and practice from a humanities perspective would be appropriate to most themes, it seems, that relate to spirituality in the workplace. Theoretical and empirical research in organisations suggests that workers have three needs: inner self-fulfilment (which is connected to spiritual needs), meaningful work in their search for purpose and an integrated life, and connectedness with fellow employees (Badrinarayanan \& Madhavaram 2008:424). Immediately one could ask what the body of knowledge on spirituality suggests for working with organisational culture, and organisational development and design. These could be interesting areas of formal inquiry for practical-theological facilitation.

With having made reference to aesthetics, wisdom and the like, I want to tie this section back to Brammer's (1979) work. Brammer (1979:11) sees helping (in my context, relating to skilled helping) as both a science and an art. Science to him implies elaborate research and theory on helping such as from the behavioural sciences (Brammer 1979:11).

On the other hand, the artistic aspects of helping connote the idea of the intuitive and feeling aspects of interpersonal relationships that he sees as based largely in the humanities and creative arts (Brammer 1979:11). Informed by my conversation with Riaan, I suspect that many organisations are greatly entrenched in the scientific causality discourse that seems to relate to Brammer's (1979:11) idea of scientific inquiry - one gets the impression - as excluding the humanities, for instance. It is in all likelihood not in the dominant scientific discourses, in the area of what White and Epston (1990:80) refer to as 'logico-scientific', that the practical-theological facilitator's most important contribution lays.

\section{On adding value}

When I shared that the practical-theological facilitator might function as a consultant, this suggestion directed my conversation with Riaan to the aspect of adding value. To Riaan, value is connected to the kind of relationship that exists between the person that functions as a skilled helper and the organisation. My initial view was that the skilled helper should be a person standing outside of the company. Take note that not all consultants are from outside of a company (cf. Burtonshaw-Gunn 2010:8-16). My motivation for the 'outside imperative' was one where I did not want 20. For this kind of skilled helping (within the discipline of practical theology), sociology
becomes one of the important interdisciplinary partners. Broadly relevant in this regard see Gräb and Charbonnier (2009). 
to see the skilled helper getting tied up in politics and becoming a pawn of those that are politically most savvy. Drennon and Cervero (2002:195) write meaningfully on the politics of facilitation in consideration of, for instance, power relationships in groups and society. The classical perspective in facilitation is that a facilitator should be a neutral, third party, with no substantive decision-making authority (Schwarz 2005:27). I shared with Riaan a bit of my own story about team politics whilst being part of a macro-congregation to explain what I mean. ${ }^{21}$

The point that Riaan makes is that the outside role is not always desirable. He relates how a consultant who came highly recommended for working with Coca Cola was experienced in their company as not adding much value. He noticed that the consultant spoke of things that clearly were not relevant to the organisation's context. In terms of the specifics of our conversation, what Riaan is implying, is that he questions the ability of an external consultant (an outsider) to fully understand the inner workings and challenges of the organisation. Even more important is that a lack of insight might then lead the consultant to propose and labour matters that the organisation and its people cannot relate to. To me this underscores what is referred to as maintaining a 'notknowing' position in a narrative approach. The practicaltheological facilitator acting as a skilled facilitator (in a way still a consultant) to the organisation should still maintain a not-knowing position. ${ }^{22}$

Riaan also questioned whether consultants really add that much value. In his opinion they tend to point towards things that are perhaps only in the moment not within one's vizier. They are often seen as a luxury and are the first ones whose involvement is in jeopardy when the budget needs to be cut. Although there is no space to elaborate here, I take note of the concern, as it is something that has also been asked concerning other skilled helping relationships. Brammer (1979:12) shows toward Carkhuff's (1968) inquiries into helping that suggests that the effectiveness of professional helpers 'is much less than claimed or believed.'

\section{Legitimacy and the outside view}

Near the end of our conversation we discussed concerns that relate to legitimacy. I did not venture into explaining narrative practice and the assumption that, and how, our stories might provide legitimacy in various contexts. I approached it in terms of what we have already discussed. I shared that I once had the question asked to me: 'Would this person [the practical-theological facilitator] have a kind of management qualification?' Riaan also thought it to be a very important question.

The outside view came into consideration again. Firstly, let me be clear that with the idea of the outside view I am not making a claim to the supposed superiority of objectivity. It seems that this is where confusion might stem from. De Roest 21. From an experienced consultant's perspective see Lencioni (2006).
(1998:35) speaks of the necessity of the outside view. He draws on the cultural-anthropological distinction between an 'experience-distant' and 'experience-near' position (De Roest 1998:35). He writes within context of Christian communities, those whom, by having some kind of relationship with Christ, might find themselves surprised at being together (cf. De Roest 1998:27). Although this is not my premise, his view remains significant. According to him, the outsider (the practical theologian for instance) contributes, for example, a search for a rational explanation for a ritual practice (De Roest 1998:35) - the 'experience-distant' perspective. On this the Christian community, organisation, movement or groups involved as participants also produce their own explanations, reasons and accordingly, theories as well (De Roest 1998:35). These contributions (i.e. theories and explanations) are to De Roest (1998:35) not viewed as 'qualitate qua verifiable by academic standards'.

The practical theologian is then said to fulfil the role of a virtual member, as he or she is part of the wider religious community as a theologian (De Roest 1998:35). He or she is in the experience-near position and as a theologian is well versed in 'religious discourse and somehow committed to the public of the church at large' (De Roest 1998:35). Yet, in employing what De Roest (1998:35) refers to as social scientific instruments or in pursuing the inquiry together with a social scientist, he or she is also a virtual outsider in the experiencedistant position. De Roest (1998:35) then remarks that the practical theologian is 'likely to commute between the two complimentary perspectives, and both perspectives should be accounted for in a scientific manner.'

The most notable difference between De Roest (1998) and my point of departure is that the communities I have in mind are more diverse. The community is not in the first instance viewed as a Christian community or even a religious community per se. I employ the metaphor of the outside view in the other direction, for the reason that the particular tradition in practical theology I am situated in represents a different epistemic community. The outside view is therefore one of a different expression of human rationality, and as such is not viewed as contributing the (only and/or best) supposed rational perspective. It is not about providing an evaluation of scientific perspective. I would find De Roest's (cf. 1998:35) contention mostly credible if it was based on the notion of the outside position offering a different epistemological view. Otherwise, the implication would be that theology should always look to other sciences, as if that is the outside view, in order to have legitimacy. On this, both science and religion share in the resources of human rationality (Van Huyssteen 2000a:431). It is of significance that our cognitive fluidity (the result of evolutionary biology (Van Huyssteen 2000b:433, 2006:39) - for which it appears our minds are hard wired (Van Huyssteen 2006:197) - 'allowed for the possibility of powerful metaphors and analogy without which science, religion, and art could not exist' (Van Huyssteen 2006:42-43). So then, to me, offering an outside view does not have the connotation of providing legitimacy or a better kind of knowledge. 
Research psychologist Daniel Kahneman, who received a Nobel Prize for his work in economics (concerned with judgement and decision-making) (2011:10), also sees merit in the outside view to, amongst other things, avoid the familiar 'planning fallacy'. I see the merit for the outside view (apart from the planning fallacy), as having to do with an aspect of how the brain works, ${ }^{23}$ that is, according to the principle of 'what you see is all there is' (WYSIATI) (Kahneman 2011:85-88, 247-248). The implication of Kahneman's work is that the human species is not as rational as one might tend to think. This is partly due to what is called the 'System 1' operation of the brain, which Kahneman says is 'a machine for jumping to conclusions' (Kahneman 2011:79). ${ }^{24}$

Let me not go into this at length. What is important here, is that our intention as practical-theological facilitators is not to correct supposed wrong thinking through argumentative reasoning ${ }^{25}$ as it might come across, considering I involve Kahneman (2011) here. We rather facilitate and tell stories (also our own). Since our contexts differ, it offers different realities (outside perspectives). These realities are not meant to be remedial, but do form part of the social construction of reality.

\section{A different kind of species}

Based on my conversation with Riaan I now differentiate between what might be understood as an 'outsider view' and the 'outside view.' Whereas an external consultant is most clearly an outsider - this could lend itself to opportunities and challenges - it is also possible for the outside view to come from within.

The metaphors I employed when describing to Riaan the relationship between the practical-theological facilitator and the organisation, such as between Merlin and King Arthur, was not intended to solicit the notion of wisdom. That is what Riaan picked up on, and I found his comments useful in the development of my ideas (such as in differentiating between the outsider view and an outside view).

My intention was to explain that the role of the practicaltheological facilitator was of a different kind than those roles one will necessarily find in the organisation. More importantly than whether the practical-theological facilitator comes from within the organisation or not, is that in the way I conceive of it, he or she is part of a different epistemic species. Merlin, for instance, belongs to the class of magic, and there is nothing in the formal offices of the kingdom that relates to his role.

23.More specifically he refers to the, so-called, 'System 1' of the brain that functions according to one's associative memory (Kahneman 2011:13). System 1 'continually constructs a coherent interpretation [based on association] of what is going on in our world at any instant' (Kahneman 2011:13).

24.System 2 is said to 'allocate attention to the effortful mental activities that demand it' (Kahneman 2011:21). It is very clear though, that System 1 is very successful at ourselves in, academic or otherwise, we are immensely prone to bias (Kahneman 2011).

25.See Müller (2011), and White and Epston (1990:77) respectively for referencing the transition from argumentative reasoning to narrative, and from 'logico-scientific' to narrative modes of thought.
This has implications for what kind of qualification is needed, whether in management or psychology:

1. Presenting the person of the practical-theological facilitator as a different sort of species allows for the idea that he or she does not first and foremost have to have a management or business qualification. What the practical-theological facilitator brings to any particular context is not less of something more that psychology and management sciences are able to offer. It is in some respects merely different; something not part of the usual prominent discourses. It involves offering an outside view informed by a different epistemic community.

2. All the modalities of interaction, such as coaching, therapy, and facilitation are non-directive to begin with. It places less emphasis, as conventional consultancy would, on content knowledge. In terms of facilitation, for instance, Bens (2005:28) notes that, in her experience the command and control type leadership is in decline. Coaching also experienced the development towards many non-directive models and approaches (Cox, Bachkirova \& Clutterbuck 2010:2-3). Consultancy practices attempt to add value by following one of three approaches that Edgar Schein pointed towards 40 years ago: a content specialist approach, a process consultancy approach, or an intermediate understanding of a doctor-patient approach (Burtonshaw-Gunn 2010:9). At the expert or specialist position, the consultant temporarily takes ownership of the problem, and the consultant's expert knowledge is put to work (Burtonshaw-Gun 2010:9). A process consultant uses the client's expertise or knowledge and the client holds ownership of the problem (BurtonshawGunn 2010:9).

3. Management and business learning can be part of a qualification that is not necessarily a management or business degree. For many years there has been a reliance on learning theories and psychology in for instance faith education and pastoral care without receiving a teaching or psychology degree. Not having an explicit psychology or education-related degree, but perhaps having had rigorous training in these matters, did not mean that the person situated in the congregational context is less competent.

\section{Closing remarks}

This article portrayed the practical-theological facilitator as a skilled helper. In closing I offer a succinct outline: Skilled helping seeks particular expression in the public domain. The organisational context is regarded as an important aspect of the public domain or audience. As such, content knowledge is to a degree necessary, as a great deal of what shapes public life, opinion, reality has to do with organisations (these may include private, or public companies, government, various institutions, and so on). Rather than the focus being content knowledge per se, seeking knowledge of content has to do with acquiring a language and adequately engaging organisational culture. 
My interview with Riaan revolved around the potential value contribution of skilled helping in the organisational context as offered by the practical-theological facilitator. The exploration saw an emphasis on wisdom and the role of the skilled helper in relation to the organisation. Cognisance is specially taken of the concern with being an outsider and how much value an outsider can really be seen to contribute.

As part of the reflection on the interview, this article had put forward skilled helping as having a strong affinity with the humanities; in the immediate context of the interview, particularly in relation to a wisdom-making role, but also spirituality. Situated in an epistemic community believed to often be different than those that organisations belong to, the practical-theological facilitator offers an outside view (not necessarily an outsider view). The outside view is preferably offered in the form of the skilled helper's story. It was said that the epistemology that informs this view relates to postfoundationalism and social constructionism.

Whilst skilled helping can add value in the organisational context, ongoing conversation with stakeholders is needed for the purpose of clarity and development of theory and practice.

\section{Acknowledgements Competing interests}

The author declares that he has no financial or personal relationship(s) which may have adversely affected the writing of the article.

\section{References}

Badrinarayanan, V. \& Madhavaram, S., 2008, 'Workplace spirituality and the selling organisation: A conceptual framework and research propositions', Journal of Personal Selling and Sales Management 28(4), 421-434. http://dx.doi.org/10.2753/ PSS0885-3134280406

Bens, I., 2005, Facilitating with ease. Core skills for facilitators, team leaders and members, managers, consultants, and trainers, 2nd edn., Jossey Bass, San Francisco, CA.

Brammer, L.M., 1979, The helping relationship. Process and skills, 2nd edn., PrenticeHall, Englewood Cliffs, NJ.

Browning, D.S., 1991, A fundamental practical theology. Descriptive and strategic proposals, Fortress Press, Minneapolis, MN

Burtonshaw-Gunn, S.A., 2010, Essential tools for management consulting. Tools, models and approaches for clients and consultants, John Wiley \& Sons, West Sussex.

Carkhuff, R., 1968, 'Differential functioning of lay and professional helpers', J. Consulting Psychology 15, 117-126.

Cox, E., Bachkirova, T. \& Clutterbuck, D.A. (eds.), 2010, The complete handbook of coaching, SAGE, London.

Daft, R.L., 2010, Organisation theory and design, 10th edn., Cengage learning, Mason, $\mathrm{OH}$.

Demasure, K., 2005, 'Lectures on the hermeneutics of Paul Ricoeur and an introduction to social constructionism', presented at the University of Pretoria, Pretoria, 27 September.

De Roest, H., 1998, Communicative identity: Habermas' perspectives of discourse as a support for practical theology, Uitgeverij Kok, Kampen.

Drennon, C.E. \& Cervero, R.M., 2002, 'The politics of facilitation in practitioner inquiry groups', Adult Education Quarterly 52(3), 193-209. http://dx.doi.org/10.1177/ 0741713602052003003

Egan, G., 2013, The skilled helper: A problem-management and opportunity-development approach to helping, 10th edn., Brooks Cole, Pacific Grove, CA.

Freedman, J. \& Combs, G., 1996, Narrative therapy: The social construction of preferred realities, W.W. Norton and Company, New York, NY.

Ganzevoort, R.R., 2009, 'Forks in the road when tracing the sacred. Practical theology as hermeneutics of lived religion', presidential address to the International Academy of Practical Theology, Catholic Theological Union, Chicago, 30 July - 03 August, viewed 04 February 2013, from http://www.ruardganzevoort.nl/pdf/2009_Presidential.pdf

Ganzevoort, R.R., 2013, email, 11 February, email address undisclosed.
Gerkin, C.V., 1986, Widening the horizons: Pastoral responses to a fragmented society, Westminster Press, Philadelphia, PA.

Gerkin, C.V., 1991, Prophetic pastoral practice, A Christian vision of life together, Abingdon Press, Nashville, TN.

Greenleaf, n.d., Robert K. Greenleaf Centre for Servant Leadership, viewed 30 July 2013, from http://www.greenleaf.org/

Greenleaf, R.K., 2002, Servant leadership. A journey into the nature of legitimate power and greatness, 25th anv. edn., Paulist Press, Mahwah, NJ.

Giacalone, R.A. \& Jurkiewicz, L.J. (eds.), 2010, Handbook of workplace spirituality and organizational performance, 2nd edn., M.E. Sharpe, Armonk, NY. PMCid:PMC2923345

Gräb, W. \& Charbonnier, L. (eds.), 2009, Secularization theories, religious identity and practical theology. Developing international practical theology for the 21st century international academy of practical theology, vol. 7, Lit Verlag, Berlin. (International international academy
Practical Theology).

Griffith, J.L. \& Griffith, M.E., 2002, Encountering the sacred in psychotherapy. How to talk with people about their spiritual lives, Guilford Press, New York, NY.

Kahneman, D., 2011, Thinking, fast and slow, Penguin Books, London. PMid:21714386 Kroes, N., 2005, 'Better regulation of professional services', in europa.eu, viewed 30 July 2013, from http://europa.eu/rapid/press-release_SPEECH-05-711_en.htm?locale=en

Lencioni, P., 2006, Silos, Politics and turf wars: A leadership fable about destroying the barriers that turn colleagues into competitors, Jossey-Bass, San Francisco, CA. the barriers that turn
PMCid:PMC2117088

Müller, J.C., 1996, Om tot verhaal te kom: Pastorale gesinsterapie, RGN Uitgewery, Pretoria.

Müller, J.C., 2011, 'Postfoundational practical theology for a time of transition', HTS Teologiese Studies/Theological Studies 67(1), Art. \#837, 5 pages. http://dx.doi. org/10.4102/hts.v67i1.837

Pienaar, H.E., 2005, 'An explorative study on the interaction between the arts and narrative practice', PhD thesis, Department of Practical Theology, University of Pretoria.

Pienaar, H.E., 2012, 'Overture to practical theological facilitation', Nederduitse Gereformeerde Teologiese Tydskrif 53(3/4), 241-255.

Pienaar, H.E. \& Müller, J.C., 2012, 'The practical theologian as decentred but influential facilitator', HTS Teologiese Studies/ Theological Studies 68(2), Art. \#1307, 10 pages. http://dx.doi.org/10.4102/hts.v68i2.1307

Nationalarchives, n.d, Defining key concepts: Products vs. services, viewed 30 July 2013, from http://www.archives.gov/preservation/products/definitions/productsservices.html

Rowan, J., 2010, 'The transpersonal approach to coaching', in E. Cox, T. Bachkirova \& D. Clutterbuck (eds.), The complete handbook of coaching, pp. 146-157, SAGE, London.

Sellers, J., 2011, 'Spiritual and religious traditions', in L. Wildflower \& D. Brennan (eds.), The handbook of knowledge-based coaching. From theory to practice, pp. 187-194 Jossey-Bass, San Francisco, CA.

Schwarz, R., 2005, 'Using facilitative skills in different roles', in R. Schwarz., A. Davidson., P. Carlson. \& S. McKinney (eds.), The skilled facilitator fieldbook: Tips, tools, and tested methods for consultants, facilitators, managers, trainers, and coaches, pp. 27-32, Jossey-Bass, San Francisco, CA.

Tracy, D., 1981, The analogical imagination. Christian theology and the culture of pluralism, SCM Press, London. PMCid:PMC1249447

Tracy, D., 1994, On naming the present: Reflections on God, hermeneutics, and church, Orbis Books, New York, NY.

Tracy, D., 1998, The analogical imagination: Christian theology and the culture of pluralism, The Crossroad Publishing Company, New York, NY.

Tracy, D., 2011, 'A correlational model of practical theology revisited', in E. Foley (ed.), Religion, diversity and conflict (International Practical Theology), vol. 15, pp. 49-64, Lit Verlag, Berlin.

Van Huyssteen, J.W., 2000a, 'Postfoundationalism and interdisciplinarity. A response to Jerome Stone', Zygon 35(2), 247-439. http://dx.doi.org/10.1111/0591-2385.00285

Van Huyssteen, J.W., 2000b, 'Pluralism and interdisciplinarity: In search of theology's public voice', in C.W. du Toit (ed.), Evolution and creativity, pp. 217-249, Research Institute for Theology and Religion, UNISA, Pretoria.

Van Huyssteen, J.W., 2006, Alone in the world? Human uniqueness in science and theology: The Gifford Lectures, Eerdmans Publishing Co., Grand Rapids, MI. PMid:16645122

Volf, M. \& Bass, D.C. (eds.), 2002, Practicing theology. Beliefs and practices in Christian life, Eerdmans Publishing Co., Grand Rapids, MI.

Weick, K.E., 1995, Sensemaking in organizations. Foundations for organizational science, SAGE, Thousand Oaks, CA.

Weick, K.E., 2009, Making sense of the organization. The impermanent organization, vol. 2, John Wiley \& Sons Ltd, Chichester.

White, M. \& Epston, D., 1990, Narrative means to therapeutic ends, W.W. Norton \& Company, London.

Whitmore, J., 2003, Coaching for performance. Growing people performance and purpose, 3rd edn., Nicholas Brealey Publishing, London.

Whybrow, A. \& Wildflower, L., 2011, 'Humanistic and transpersonal psychology', in L. Wildflower \& D. Brennan (eds.), The handbook of knowledge-based coaching. From theory to practice, pp. 3-10, Jossey-Bass, San Francisco, CA.

Wikipedia, n.d., Services marketing, viewed 30 July 2013, from http://en.wikipedia. org/wiki/Services_marketing\#References

World Economic Forum, n.d., Issues, viewed 05 February 2013, from http://www. weforum.org/issues 